\title{
Detection of Zika virus in paired urine and amniotic fluid samples from symptomatic and asymptomatic women and their babies during a disease outbreak: association with neurological symptoms in newborns
}

\author{
Danila Vedovello $^{1}$ (D) Steven S. Witkin ${ }^{2,3}$. Andrea Cristina Botelho Silva ${ }^{1} \cdot$ Thamirys Cosmo Gillo Fajardo $^{1}$. \\ Alexandra Siqueira Mello ${ }^{1}$ - Ana Paula Antunes Pascalicchio Bertozzi ${ }^{1,2}$ - Alify Bertoldo da Silva ${ }^{2}$. \\ Nemésio Florence Vieira Filho ${ }^{2}$ - Maria Manoela Duarte Rodrigues ${ }^{2}$ - Rosa Estela Gazeta ${ }^{2}$. \\ Antônio Fernandes Moron ${ }^{4}$ - Stéphanno Gomes Pereira Sarmento ${ }^{5}$ - Antonio Soriano-Arandes ${ }^{6}$. \\ Saulo Duarte Passos ${ }^{1,2}$
}

Received: 8 March 2019 / Revised: 15 August 2019 / Accepted: 21 August 2019 / Published online: 9 September 2019

(C) The Author(s) 2019

\begin{abstract}
Paired maternal and newborn urine and amniotic fluid from 138 subjects collected during a Zika virus (ZIKV) outbreak was analyzed for ZIKV by gene amplification (RT-qPCR), and the findings were correlated with clinical symptoms and neurological anomalies in the babies. ZIKV was detected in 1 of 9 symptomatic women $(11.1 \%)$ and in 19 of 129 asymptomatic women (14.7\%). Neurological manifestations were present in 19 babies (13.7\%), 10 of $20(50 \%)$ positive and 9 of $119(7.6 \%)$ negative ( $p$ $<0.001)$ for ZIKV. Twelve $(8.6 \%)$ urines collected during gestation were ZIKV-positive; only 2 remained positive for ZIKV postpartum. Six (4.1\%) newborn urines collected within 1 day of delivery were ZIKV-positive cases. In 3 of these cases, ZIKV was detected in mother's urine pre- and postpartum and in both mother's urine and babies' urine. Four of the amniotic fluid samples (2.9\%) were ZIKV-positive. Among ZIKV-negative babies with neurological sequel, 87.5\% were female; in contrast, $72.7 \%$ ZIKV-positive babies with neurological abnormalities were male $(p=0.019)$. We conclude that during a ZIKV outbreak, clinical symptoms and ZIKV detection in biological fluids are poor predictors of infection and adverse neurologic sequel in newborns.
\end{abstract}

Keywords Zika virus $\cdot$ Pregnancy $\cdot$ Neurological symptoms $\cdot$ Urine $\cdot$ Amniotic fluid

$\overline{\text { Danila Vedovello and Steven S. Witkin contributed equally to this work. }}$

Danila Vedovello

danvedo@hotmail.com

1 Laboratory of Pediatric Infectology, Jundiaí School of Medicine, Rua Francisco Telles, 250, Vila Arens, Jundiaí, SP 13202-550, Brazil

2 Jundiaí School of Medicine, University Hospital, Jundiaí, SP, Brazil

3 Weill Cornell Medicine, New York, NY, USA

4 Neonatal Perinatal Medical Forum, Paulista Federal Medical School, São Paulo, SP, Brazil

5 Paulista Center for Fetal Medicine, Paulista Federal Medical School, São Paulo, SP, Brazil

6 Pediatric Infectious Diseases Unit, Hospital Universitari Vall d'Hebron, Barcelona, Spain

\section{Introduction}

Zika virus (ZIKV) is an arbovirus and member of the Flaviviridae family that also includes the Yellow Fever Virus, Dengue Virus, West Nile Virus, Japanese Encephalitis Virus, St. Louis Encephalitis Virus, and others (Simmonds et al. 2017). ZIKV (strain MR-766) was initially isolated in the Uganda forest from sentinel monkeys in 1947 (Dick et al. 1952). It has been claimed that the first description of ZIKV in humans occurred in Nigeria in 1954 (MacNamara 1954). However, studies have shown that this may have been confused with the presence of the Spondweni virus (Simpson et al. 1964; Haddow and Woodall 2016), another Flavivirus that produces symptoms similar to ZIKV and is serologically cross-reactive. Therefore, the first description of ZIKV in humans is now attributed to Simpson and collaborators in 1964 (Simpson et al. 1964). 
ZIKV re-emerged in 2007, with an epidemic on Yap Island, Micronesia (Duffy et al. 2009) followed by its spread to Oceania and to the Americas (Musso and Gubler 2016). The first detection of autochthonous ZIKV in Brazil occurred in 2015. (Zanluca et al. 2015). Initial phylogenetic analyses of seven ZIKV sequences suggested its introduction into Brazil, from endemic areas of Oceania (Faria et al. 2016). However, subsequent studies have shown that these Brazilian strains were also closely related to ZIKV strains isolated in Haiti, Central America, and the Caribbean Islands, suggesting several potential routes of spread (Campos et al. 2018).

According to the World Health Organization (WHO), the case definition of a symptomatic ZIKV infection includes a rash and/or fever and at least one of the following: arthralgia, arthritis, or conjunctivitis (WHO 2016). However, the range of symptoms varied in different affected regions. In French Polynesian and the Americas, outbreaks were generally mild and accompanied by fever, arthralgia and myalgia, conjunctivitis, headache, fatigue, and/or rash. In other regions, ZIKV elicited more severe symptoms in adults, including multiorgan failure, meningitis, encephalitis, and thrombocytopenia (Pierson and Diamond 2018).

ZIKV virulence for pregnant women and their babies in Brazil first became apparent in May 2015 (Cugola et al. 2016). The ZIKV replication cycle begins with transmission from an infected mosquito (Weaver and Reisen 2010). After initial replication in epidermal keratinocytes and Langerhans cells, the virus migrates to lymph nodes in association with monocytes, macrophages, and dendritic cells (Jurado and Iwasaki 2017). Following a primary viremia, ZIKV may infect cells in multiple organs such as the spleen, kidney, and testes. It may also cross the blood-brain barrier. In pregnant women, ZIKV can infect placental macrophages (Quicke et al. 2016).

ZIKV has been detected in blood (Jurado and Iwasaki 2017), saliva (Barzon et al. 2016), urine (Gourinat et al. 2015; Zhang et al. 2016), fetal brain (Oliveira Melo et al. 2016), and semen (Mansuy et al. 2016; Counotte et al. 2018), in cases of renal transplantation (Nogueira et al. 2017) and in amniotic fluid (Calvet et al. 2016; Benjamin et al. 2017).

In the present study, we investigated associations between maternal symptom occurrence, ZIKV detection in maternal or newborn urine and amniotic fluid, and the presence of neurological symptoms in male and female babies.

\section{Material and methods}

\section{Subjects}

The study population consisted of 138 mother-infant pairs identified from an ongoing cohort of high-risk pregnant women during a ZIKV outbreak in the city of Jundiai, State of São Paulo, Brazil, in 2016-2017. A subject was defined as having a high-risk pregnancy if she had a history of miscarriage or preterm birth or was positive for gestational diabetes mellitus (GDM), arterial hypertension, history of toxoplasmosis, hepatitis C, urinary tract infection, syphilis or other sexually transmitted diseases, an autoimmune disorder, or being obese. The inclusion criterion was the availability of maternal urine samples collected both during gestation and after delivery, amniotic fluid collected at the time of delivery, and newborn urine collected within 1 day of birth. All infants were followed up for a period of 1 year.

The presence of symptoms consistent with criteria established by the WHO for possible ZIKV infection was ascertained by direct questioning. Subjects' race was as selfreported.

All subjects provided written informed consent authorizing the use of de-identified biological samples from themselves and their babies for subsequent scientific investigation. The study was approved by the Research Ethics Committee of the Jundiai School of Medicine, CAAE 53248616.2.0000.5412.

\section{Sample collection}

Urine samples obtained from mothers during their gestation and after delivery and from their babies within 1 day of birth were collected in sterile pouches. Amniotic fluid was collected with a $20-\mathrm{mL}$ syringe at the time of delivery by an obstetrician at the University Hospital by a technique that we developed. If the delivery was by cesarean section, the obstetrician induced membrane rupture with tweezers and inserted a syringe to collect 5-10 mL of amniotic fluid. In cases of vaginal delivery, the obstetrician induced rupture of the amniotic membrane with tweezers or waited for spontaneous rupture and then collected 5-10 mL of amniotic fluid from the vagina. All samples were transferred to a sterile tube, placed in ice-water, and sent immediately to the Laboratory of Pediatric Infectious Diseases for analysis. The amniotic fluid was centrifuged at $1400 \mathrm{~g}$ for $20 \mathrm{~min}$ at $4{ }^{\circ} \mathrm{C}$ and the supernatant aliquoted into vials and stored at $-80^{\circ} \mathrm{C}$. Nine of the 138 births were twins. However, only one of these twin pregnancies was dizygotic yielding a total of 139 amniotic fluid samples for analysis.

\section{ZIKV detection}

All urine and amniotic fluid samples were analyzed for ZIKV by quantitative reverse transcriptase-polymerase chain reaction (RT-qPCR) as recommended by the Centers for Disease Control and Prevention (CDC) (Lanciotti et al. 2008). We recognize that PCR positivity may be restricted to a variable period after infection and findings should ideally be interpreted in regard to time since exposure. This was not possible in our endemic setting. The RT-qPCR was performed 
using the GoTaq ${ }^{\circledR}$ 1-Step RT-qPCR System (ㄷ 2018 Promega, Madison, WI, USA).

RNA was extracted from the biological samples by the QIAamp Viral RNA Kit (C) 2018, Qiagen, Venlo, Netherlands), following the manufacturer's instructions. Afterwards, $8 \mu \mathrm{L}$ of RNA template was mixed with $10 \mu \mathrm{L}$ of GoTaq ${ }^{\circledR}$ Probe qPCR Master Mix with dUTP $(1 \times)$ with $10 \%$ of Carboxy-X-Rhodamine (CXR), $0.4 \mu \mathrm{L}$ of GoScript ${ }^{\mathrm{TM}}$ RT Mix for 1-Step RT-qPCR (1×), $1 \mu \mathrm{L}$ of forward primer $(10 \mathrm{pmol} / \mu \mathrm{L}), 1 \mu \mathrm{L}$ of reverse primer $(10 \mathrm{pmol} / \mu \mathrm{L}), 1 \mu \mathrm{L}$ of probe $(10 \mathrm{pmol} / \mu \mathrm{L})$, and nuclease-free water to complete the final volume of $25 \mu \mathrm{L}$. Two sets of primers were used, serving as a double check.

Amplification was performed on an ABI Prism 7500 SDS Real-Time cycler Applied Biosystems (ㄷ 2016 Thermo Fisher Scientific, Waltham, MA, USA) and consisted of a 10 -min cycle at $50{ }^{\circ} \mathrm{C}$ and a 2 -min cycle at $95{ }^{\circ} \mathrm{C}$ to produce cDNA; and forty cycles of $15 \mathrm{~s}$ at $95^{\circ} \mathrm{C}$ and $1 \mathrm{~min}$ at $60^{\circ} \mathrm{C}$ for the PCR (Lanciotti et al. 2008). Three positive controls (RNA extracted from ZIKV-positive samples) and three negative controls, nuclease-free $\mathrm{H}_{2} \mathrm{O}$ (Thermo Fisher Scientific, Waltham, MA, USA) were included in each run. Samples that were amplified by the two sets of primers were considered positive. In all cases, the positive and negative controls yielded the expected results.

\section{Statistics}

Associations between numerical variables were analyzed by Fisher's exact test. Means and standard deviations were obtained using the Mann-Whitney test (Mann and Whitney 1946). A two-sided $p$ value $<0.05$ was considered significant.

\section{Results}

Characteristics of the study population are shown in Table 1. Mean age of the mothers was 28.8 years, mean gestational age at delivery was 37.9 weeks, and mean baby birth weight was $3113 \mathrm{~g}$. Nine of the women (6.5\%) delivered twins. The majority of the deliveries were by cesarean section $(82.7 \%)$ and most of the women were either White $(44.6 \%)$ or of mixed race $(31.6 \%)$.

Of the 138 urine samples collected from pregnant mothers before delivery, 12 (8.6\%) were ZIKV-positive. Postpartum, only 2 of the previously positive urine samples remained positive for ZIKV. Urine collected within 1 day of delivery from the 148 newborns (139 singletons and 9 twins) was ZIKVpositive in $6(4.1 \%)$ cases. ZIKV was detected in $4(2.9 \%)$ of the 139 amniotic fluid samples collected from the 138 women. In the dizygotic twin gestation, ZIKV was detected in one of the amniotic sacs. In total, ZIKV was detected in one of 9 women $(11.1 \%)$ who were positive for ZIKV-associated
Table 1 Characteristics of the study population

\begin{tabular}{ll}
\hline Characteristic & Value \\
\hline Mothers age (years) & $28.8(6.8)^{\mathrm{a}}$ \\
Gestational age at delivery (weeks) & $37.9(2.2)^{\mathrm{a}}$ \\
Babies birthweight (g) & $3113(643)^{\mathrm{a}}$ \\
Twins & $9(6.5 \%)$ \\
Delivery by cesarean section & $82.7 \%$ \\
Male baby & $44.6 \%$ \\
Female baby & $55.4 \%$ \\
White & $44.6 \%$ \\
Mixed race & $31.6 \%$ \\
Black & $10.8 \%$ \\
Asian & $0.7 \%$ \\
\hline
\end{tabular}

The study population consisted of 138 mother-baby pairs

${ }^{\mathrm{a}}$ Mean (standard deviation)

symptoms and in 19 of 129 women (14.7\%) who were asymptomatic.

The diagnoses of microcephaly and macrocephaly in our cohort were made using the INTERGROWTH-21(st) parameters (Papageorghiou et al. 2013). Neurological manifestations were detected in 15 babies at the time of delivery ( 9 cases of microcephaly 5 cases of macrocephaly 1 case of macrocraniania) and in an addition, four babies only at later time periods. These four cases included (a) dystonia (297 days after birth), cataract, and abnormal respiratory system in the newborn of an asymptomatic mother who was positive for ZIKV only in urine while pregnant; (b) aggravating cranial developmental problems (254 days after birth) and low visual acuity in the newborn of an asymptomatic mother, positive for ZIKV only in in urine while pregnant; (c) ventricular system of abnormal dimensions (parallelism of the lateral ventricles) and ventricular system of abnormal morphology (discrete duct distension of the supratentorial system) in the newborn of a symptomatic mother positive for ZIKV only in urine while pregnant; (d) ataxia (in 11th month of life), binocular low visual acuity (in 5th month of life), abnormal swallowing, and respiratory tract abnormal in a newborn positive for ZIKV in its urine.

Neurological manifestations were identified in babies born in 10 of 20 women (50.0\%) who were ZIKV-positive vs. only 9 of 119 women $(7.6 \%)$ who were ZIKV-negative $(p<0.001)$. Results for each of the mother-baby pair positive for ZIKV and/or neurological symptoms are shown in Table 2. In nine cases where both mother and baby were ZIKV-negative, 8 asymptomatic and one symptomatic mother, the baby manifested a neurological abnormality at birth -5 cases of microcephaly and 4 cases of macrocephaly. Of nine cases where only the mother's urine was positive during pregnancy, 4 of their babies were apparently normal, 2 had microcephaly, 1 had macrocephaly, and 2 had late sequela. One case where 
Table 2 Symptoms, Zika virus detection, and neurological problems in the newborn

\begin{tabular}{|c|c|c|c|c|c|}
\hline \multirow[t]{2}{*}{ Symptoms } & \multicolumn{4}{|l|}{ ZIKV in } & \multirow[t]{2}{*}{ Disorder } \\
\hline & Pregnancy urine & Postpartum urine & Newborn urine & Amniotic fluid & \\
\hline \multicolumn{6}{|c|}{ Asymptomatic } \\
\hline 1 & Negative & Negative & Negative & Negative & Macrocephaly \\
\hline 2 & Negative & Negative & Negative & Negative & Microcephaly \\
\hline 3 & Negative & Negative & Negative & Negative & Macrocephaly \\
\hline \multirow[t]{2}{*}{4} & Negative & Negative & Negative & Negative & T1 microcephaly \\
\hline & & & & & $\mathrm{T} 2$ negative \\
\hline 5 & Negative & Negative & Negative & Negative & Microcephaly \\
\hline 6 & Negative & Negative & Negative & Negative & Microcephaly \\
\hline 7 & Negative & Negative & Negative & Negative & Microcephaly \\
\hline \multirow[t]{2}{*}{8} & Negative & Negative & Negative & Negative & T1 negative \\
\hline & & & & & T2 macrocephaly \\
\hline 9 & Positive & Negative & Negative & Negative & Negative \\
\hline 10 & Positive & Negative & Negative & Negative & Negative \\
\hline 11 & Positive & Negative & Negative & Negative & Negative \\
\hline 12 & Positive & Negative & Negative & Negative & Negative \\
\hline 13 & Positive & Negative & Negative & Negative & Dystonia, cataracts, ventricle defects \\
\hline 14 & Positive & Negative & Negative & Negative & Microcephaly \\
\hline 15 & Positive & Negative & Negative & Negative & Macrocephaly \\
\hline 16 & Positive & Negative & Negative & Negative & Microcephaly \\
\hline 17 & Positive & Positive & Negative & Negative & Macrocraniania \\
\hline 18 & Positive & Positive & Positive & Negative & Microcephaly \\
\hline 19 & Negative & Negative & Negative & Positive & Negative \\
\hline 20 & Negative & Negative & Negative & Positive & Negative \\
\hline \multirow[t]{2}{*}{21} & Negative & Negative & Negative & $\mathrm{T} 1$ positive & Negative \\
\hline & & & & $T 2$ negative & Negative \\
\hline 22 & Positive & Negative & Negative & Positive & Negative \\
\hline 23 & Negative & Negative & Positive & Negative & Macrocephaly, duct distension \\
\hline 24 & Negative & Negative & Positive & Negative & Ataxia, vision, and respiratory problem \\
\hline 25 & Negative & Negative & Positive & Negative & Negative \\
\hline 26 & Negative & Negative & Positive & Negative & Negative \\
\hline 27 & Negative & Negative & Positive & Negative & Microcephaly \\
\hline \multicolumn{6}{|c|}{ Symptomatic } \\
\hline 1 & Negative & Negative & Negative & Negative & Macrocephaly \\
\hline 2 & Positive & Negative & Negative & Negative & Ventricular abnormalities, duct distension \\
\hline
\end{tabular}

$\mathrm{T} 1 / \mathrm{T} 2$, twin gestations

*116 newborns were negative for ZIKV and did not present at birth or late sequelae. So as their mothers, they were not positive for ZIKV either

both pregnancy and postpartum urine were ZIKV-positive was associated with a baby with macrocrania. When both pregnancy and postpartum urine and newborn urine were ZIKV-positive, the baby had microcephaly. In the six cases where only the newborns' urine was positive, two of the babies did not manifest any abnormalities, 2 had microcephaly, and 2 had late neurological manifestations. In the 4 cases of ZIKV detection only in amniotic fluid, all babies appeared unaffected. Among the ZIKV-positive mothers, 3 entered the high-risk pool due to GDM and one each because of obesity, hypothyroidism, chronic arterial hypertension, pulmonary disease, or a hematological disorder. The distribution of risks necessitating entry into the high-risk pregnancy pool was not different between ZIKV-positive or -negative mothers and there was no association between newborn neurological manifestations and identified pregnancy risk (data not shown). Strikingly, among the ZIKV-negative babies with neurological sequel, $87.5 \%$ were female; conversely, $72.7 \%$ of ZIKVpositive babies with neurological abnormalities were male $(p=0.019)$. 


\section{Discussion}

Consequences of ZIKV in pregnant women are variable among different populations and factors associated with the most serious pathology-neurological disorders in their newborns - remain incompletely determined. In the present study of a high-risk pregnancy population evaluated during the time of a ZIKV outbreak, we report that adverse neurological sequela was identified in $50 \%$ of cases in which women had ZIKV detected in their urine during gestation and/or postpartum and/or in their newborn's urine. Thus, these findings are consistent with previous studies on the strong association between ZIKV infection during pregnancy and neurological pathology in their offspring (Walter et al. 2018; Russo et al. 2017; Li et al. 2016) and, furthermore, that maternal ZIKV infection does not always adversely affect the involved neonates (Pomar et al. 2018). Newborn neurological problems were also identified in $7.6 \%$ of cases in which ZIKV was not detected in any sample. This implies that, especially during ZIKV outbreaks, the absence of ZIKV detection does not necessarily mean that the fetus will not become infected and suffer adverse consequences.

All babies with adverse neurological disorders were from mothers with ZIKV-negative amniotic fluid and none of the 4 cases of ZIKV detection in amniotic fluid was associated with a fetal neurological anomaly.

Babies with neurological defects but who along with their mothers were negative for ZIKV detection were almost all female, while, conversely, neurological defects in association with maternal or neonatal ZIKV detection were almost all in males. This suggests a possible influence of fetal sex on ZIKV titer at different body sites and/or variations in the likelihood of transplacental infection. These areas deserve further study.

Our observations were made during a ZIKV outbreak. This suggests the involvement of this virus in the neurological sequela, even in those cases where ZIKV was not detected by RT-qPCR. ZIKV-positive urine is a transient occurrence (Zhang et al. 2016) and may have been no longer present in some of the positive cases. Our findings complement previous investigations highlighting the variable consequences for newborns of having a mother who is ZIKV-positive (Wheeler et al. 2018) as well as the occurrence of adverse neurological consequences in babies whose mothers did not have detectable ZIKV during their gestation (Nogueira et al. 2018). The rates of detection of ZIKV in maternal or neonatal urine in our study population is consistent with what has been reported previously (Gourinat et al. 2015) and is most likely a consequence of the transient nature of ZIKV infection at this site (Zhang et al. 2016). In addition, it is possible that ZIKV may not infect the urinary tract in all cases of infection.

Limitations of the present study need to be acknowledged. Symptoms in our pregnant population were self-reported and so are prone to recall bias. We attempted to minimize this possibility by conducting interviews with highly trained personnel, but this remains a possibility. The timing of ZIKV infection has been shown to influence the rate of viral detection in biological fluids, the occurrence of transplacental viral passage, and neonatal adverse effects (Cao et al. 2017). Unfortunately, in the present study, this information could not be obtained. Almost all subjects came to our clinic in their late second trimester. The lack of concordance between ZIKV detection at the different sampling sites in most subjects in our study might possibly be due to technical failure, although our assay for ZIKV detection included controls that ruled out the possible presence of inhibitors of gene amplification. Differences in viral load between samples at the various sites and/or variations in ZIKV concentration at the same site between individual women would also account for the observed inconsistencies in viral detection. These samples were collected post-delivery. Conversely, we acknowledge that our technique of collecting amniotic fluid from women with vaginal delivery is prone to contamination by maternal blood and/or vaginal secretions.

There are multiple infectious and genetic causes of microcephaly and macrocephaly (Devakumar et al. 2018; Gilmore and Walsh 2012; Passemard et al. 2013). Unfortunately, we were unable to test for antibodies to flaviviruses. There is a hypothesis that the simultaneous presence of more than one flavivirus infection may potentiate negative sequelae. However, these studies are not definitive and need further exploration (Badolato-Correa et al. 2018). Even in animal models, the results are still inclusive (Langerak et al. 2019).

Other arboviruses such as Dengue and Chikungunya are common in Brazil. Therefore, the contribution of other viruses to the observed neurological problems cannot be definitely excluded. Macrocephaly has been previously been described in ZIKV-positive neonates (Levine et al. 2017; Chimelli et al. 2017), and the present study supports this as a possible ZIKVrelated outcome. One of the babies with macrocephaly was from a mother with GDM. In this case, we cannot distinguish if this neurological problem was a consequence of the GDM, ZIKV infection, or both. Further investigations are required to determine under which circumstances a congenital ZIKV infection can predispose to macrocephaly.

We conclude that while ZIKV detection in maternal and newborn urine is associated with the subsequent occurrence of neurological problems in newborns or at later times in postnatal development, the variables associated with transplacental passage of the virus and induction of neurological pathology in the developing baby still remain largely undetermined. In addition, due at least in part to individual variability in rates of viral replication and/or persistence at different sites, the absence of ZIKV detection does not necessarily mean the absence or infection or guarantee that the fetus was not infected or may have neurological abnormalities. Therefore, we strongly recommend that periodic ultrasound measurements 
are performed in all fetuses regardless of the mothers' ZIKV status during periods of ZIKV prevalence.

Acknowledgments We gratefully acknowledge contributions from all volunteers of these Research Project (Coorte Zika—Jundiai); the support of Faculdade de Medicina de Jundiai (FMJ) and Hospital Universitário (HU); the Obstetrics Department of FMJ; the Rede Nacional de Especialistas em Zika e Doenças Correlatas (RENE ZIKA-Ministério da Saúde do Brasil/ MoH) for the donation of several diagnostic kits, insumes, and supplies; the Salesforce Inc. for the donation of an online platform use license; and a special thanks to Laura Cunha Rodrigues, Professor of Infectious Disease Epidemiology of London School of Hygiene and Tropical Medicine, for her fundamental support for this research project.

We gratefully acknowledge the Scientific Researches Group, named on Cohort Zika Jundiai Consortium* that includes and has included, in addition to the authors of this paper: Allan Rodriguez, Danila Soares Tambalo, Dora Fix Ventura, Eduardo Massad, Eduardo Roberto Bagne, Fabiana Martins Soares de Souza, Fatima Rizzo, Fernanda Guerra Velasco, Gabriel Uerlings Zanquetta, Lucas Castro Pires, Lucas Rodrigues Laranja, Mayana Zatz, Marcia Furquim de Almeida, Maria de Fatima Valente Rizzo, Matheus Sene, Natalie Borges Santos, Priscila de Oliveira Costa Santos, Nuria Sánchez Clemente, Raianny Augusta Rosario de Oliveira, Renata Mizani, Rita de Cássia de Aguirre Bernardes Dezena, Sandra Helena Alves Bonom, Silvia Maria Ribeiro Oyama, Tathiana Ghisi de Souza, Vivian Paschoarelli, and as many volunteer researchers.

Funding information This work was supported by Fundação de Amparo à Pesquisa do Estado de São Paulo (SDP \#grant 2016/08578-0 and DV \#grant 2017/22007-8), London School of Hygiene and Tropical Medicine (SDP \#grant PC0002/16), Ministry of Health of Brazil MoH (SDP \#grant 861306/2017 and 861307/2017), and World Health Organization (SDP \#grant ZIKV100/2018).

\section{Compliance with ethical standards}

The study was approved by the Research Ethics Committee of the Jundiai School of Medicine, CAAE 53248616.2.0000.5412.

Open Access This article is distributed under the terms of the Creative Commons Attribution 4.0 International License (http:// creativecommons.org/licenses/by/4.0/), which permits unrestricted use, distribution, and reproduction in any medium, provided you give appropriate credit to the original author(s) and the source, provide a link to the Creative Commons license, and indicate if changes were made.

\section{References}

Badolato-Correa J, Sanchez-Arcila JC, de Souza TMA, Barbosa LS, Nunes PCG, Lima MRQ, Gandini M, de Filippis AMB, da Cunha RV, de Azeredo EL, de-Oliveira-Pinto LM. (2018). Human T cell responses to Dengue and Zika virus infection compared to Dengue/ Zika coinfection. Immun Inflammation Dis 6(2):194-206. https:// doi.org/10.1002/iid3.203

Barzon L, Pacenti M, Berto A, Sinigaglia A, Franchin E, Lavezzo E, Brugnaro P, Palú G (2016) Isolation of infectious Zika virus from saliva and prolonged viral RNA shedding in a traveller returning from the Dominican Republic to Italy, January 2016. Euro Surveill 21(10):30159. https://doi.org/10.2807/1560-7917.ES.2016.21.10. 30159
Benjamin I, Fernández G, Figueira JV, Parpacén L, Urbina MT, Medina R (2017) Zika virus detected in amniotic fluid and umbilical cord blood in an in vitro fertilization-conceived pregnancy in Venezuela. Fertil Steril 107(6):1319-1322. https://doi.org/10.1016/ j.fertnstert.2017.02.112

Calvet G, Aguiar RS, Melo ASO, Sampaio SA, Filippis BI, Fabri A, Araujo EMS, Sequeira PC, Mendonça MCL, Oliveira L, Tschoeke DA, Schrago CG, Thompson FL, Brasil P, Santos FB, Nogueira RMR, Tanuri A, Filippis AMB (2016) Detection and sequencing of Zika virus from amniotic fluid of fetuses with microcephaly in Brazil: a case study. Lancet Infect Dis 16(6):653-660. https://doi. org/10.1016/S1473-3099(16)00095-5

Campos TL, Durães-Carvalho R, Rezende AM, Carvalho OV, Kohl A, Wallau GL, Pena LJ (2018) Revisiting key entry routes of human epidemic arboviruses into the mainland Americas through largescale phylogenomics. Int J Genomics 2018:6941735. https://doi. org $/ 10.1155 / 2018 / 6941735$

Cao B, Diamond MS, Mysorekar IU (2017) Maternal-fetal transmission of Zika virus: routes and signals for infection. J Interf Cytokine Res 37(7):287-294. https://doi.org/10.1089/jir.2017.0011

Chimelli L, Melo ASO, Avvad-Portari E, Wiley CA, Camacho AHS, Lopes VS, Machado HN, Andrade CV, Dock DCA, Moreira ME, Tovar-Moll F, Oliveira-Szejnfeld PS, Carvalho ACG, Ugarte ON, Batista AGM, Amorim MMR, Melo FO, Ferreira TA, Marinho JRL, Azevedo GS, Leal JIBF, da Costa RFM, Rehen S, Arruda MB, Brindeiro RM, Delvechio R, Aguiar RS, Tanuri A (2017) The spectrum of neuropathological changes assciated with congenital Zika vírus infection. Acta Neuropathol 133(6):983-999

Counotte MJ, Kim CR, Wang J, Bernstein K, Deal CD, Broutet JN, Low N (2018) Sexual transmission of Zika virus and other flaviviruses: a living systematic review. PLoS Med 15(7):e1002611. https://doi. org/10.1371/journal.pmed.1002611

Cugola FR, Fernandes IR, Russo FR, Freitas BC, Dias JLM, Guimarães KP, Benazzato C, Almeida N, Pignatari GC, Romero S, Polonio $\mathrm{CM}$, Cunha I, Freitas CL, Brandão WN, Rossato C, Andrade DG, Faria DP, Garcez AT, Buchpigel CA, Braconi CT, Mendes E, Sall AA, Zanotto PMA, Peron JPS, Muotri AR, Beltrão-Braga P (2016) The Brazilian Zika virus strain causes birth defects in experimental models. Nature 534:267-271. https://doi.org/10.1038/nature18296

Devakumar D, Bamford A, Ferreira MU, Broad J, Rosch RE, Groce N, Breuer J, Cardoso MA, Copp AJ, Alexandre P, Rodrigues LC, Abubakar I (2018) Infectious causes of microcephaly: epidemiology, pathogenesis, diagnosis, and management. Lancet Infect Dis 18(1):e1-e13. https://doi.org/10.1016/S1473-3099(17)30398-5

Dick GW, Kitchen SF, Haddow AJ (1952) Zika virus. I Isolations and serological specificity. Trans R Soc Trop Med Hyg 46(5):509-520

Duffy MR, Chen T, Hancock WT, Powers AM, Jacob L, Kool JL, Lanciotti RS, Pretrick M, Marfel M, Holzbauer S, Dubray C, Guillaumot L, Griggs A, Martin B, Lambert AJ, Laven J, Kosoy O, Panella A, Biggerstaff BJ, Fischer M, Hayes EB (2009) Zika virus outbreak on Yap Island, Federated States of Micronesia. N Eng1 J Med 360:2536-2543. https://doi.org/10.1056/ NEJMoa0805715

Faria NR, Azevedo RSS, Kraemer MUG et al (2016) Zika virus in the Americas: early epidemiological and genetic findings. Science 352(6283):345-349. https://doi.org/10.1126/science.aaf5036

Gilmore EC, Walsh CA (2012) Genetic causes of microcephaly and lessons for neuronal development. Wiley Interdiscip Rev Dev Biol 2(4):461-478. https://doi.org/10.1002/wdev.89

Gourinat AC, O'Connor O, Calvez E, Goarant C, Dupont-Rouzeyrol M (2015) Detection of Zika virus in urine. Emerg Infect Dis 21(1):84 86. https://doi.org/10.3201/eid2101.140894

Haddow, AD and Woodall, JP (2016). Distinguishing between Zika and Spondweni viruses. Bull World Health Organ 94:711-711A. https:// doi.org/10.2471/BLT.16.181503 
Jurado KA, Iwasaki A (2017) Zika virus targets blood monocytes. Nat Microbiol 2(11):1460-1461. https://doi.org/10.1038/s41564-0170049-7

Lanciotti RS, Kosoy OL, Laven JJ, Velez JO, Lambert AJ, Johnson AJ, Stanfield SM, Duffy MR (2008) Genetic and serologic properties of Zika virus associated with an epidemic, Yap State, Micronesia, 2007. Emerg Infect Dis 14(8):1232-1239. https://doi.org/10.3201/ eid1408.080287

Langerak T, Mumtaz N, Tolk VI, van Gorp ECM, Martina BE, Rockx B, Koopmans MPG (2019) The possible role of cross-reactive dengue virus antibodies in Zika virus pathogenesis. PLoS Pathog 15(4): e1007640. https://doi.org/10.1371/journal.ppat.1007640

Levine D, Jani JC, Castro-Aragon I, Cannie M (2017) How does imaging of congenital Zika compare with imaging of other STORCH infections? Radiology 285(3):744-761

Li H, Saucedo-Cuevas L, Shresta S, Gleeson JG (2016) The neurobiology of Zika virus. Neuron 92(5):949-958. https://doi.org/10.1016/j. neuron.2016.11.031

MacNamara FN (1954) Zika virus: a report on three cases of human infection during an epidemic of jaundice in Nigeria. Trans R Soc Trop Med Hyg 48(2):139-145. https://doi.org/10.1016/00359203(54)90006-1

Mann HB, Whitney DR (1946) On a test of whether one of two random variables is stochastically larger than the other. Ann Math Stat 18(1): 50-60. https://doi.org/10.1214/aoms/1177730491

Mansuy JM, Suberbielle E, Chapuy-Regaud S, Mengelle C, Bujan L, Marchou B, Delobel P, Gonzalez-Dunia D, Malnou CM, Izopet J, Martin-Blondel G (2016) Zika virus in semen and spermatozoa. Lancet Infect Dis 16(10):1106-1107. https://doi.org/10.1016/ S1473-3099(16)30336-X

Musso D, Gubler DJ (2016) Zika virus. Clin Microbiol Ver 29(3):487524. https://doi.org/10.1128/CMR.00072-15

Nogueira ML, Estofolete CF, Terzian AC, Mascarin do Vale EP, da Silva RC, da Silva RF, Ramalho HJ, Fernandes Charpiot IM, Vasilakis N, Abbud-Filho M (2017) Zika virus infection and solid organ transplantation: a new challenge. Am J Transplant 17(3):791-795. https://doi.org/10.1111/ajt.14047

Nogueira ML, Nery Júnior NRR, Estofolete CF, Bernardes Terzian AC, Guimarães GF, Zini N, Alves da Silva R, Dutra Silva GC, Junqueira Franco LC, Rahal P, Bittar C, Carneiro B, Vasconcelos PFC, Freitas Henriques D, Barbosa DMU, Lopes Rombola P, de Grande L, Negri Reis AF, Palomares SA, Wakai Catelan M, Cruz LEAA, Necchi SH, Mendonça RCV, Penha Dos Santos IN, Alavarse Caron SB, Costa F, Bozza FA, Soares de Souza A, Brandão de Mattos CC, de Mattos LC, Vasilakis N, Oliani AH, Vaz Oliani DCM, Ko AI (2018) Adverse birth outcomes associated with Zika virus exposure during pregnancy in São José do Rio Preto, Brazil. Clin Microbiol Infect 24(6):646-652. https://doi.org/10.1016/j.cmi.2017.11.004

Oliveira Melo AS, Malinger G, Ximenes R, Szejnfeld PO, Alves Sampaio S, Bispo de Filippis AM (2016) Zika virus intrauterine infection causes fetal brain abnormality and microcephaly: tip of the iceberg? Ultrasound Obstet Gynecol 47(1):6-7. https://doi.org/ 10.1002/uog. 15831

Papageorghiou AT, Lambert A, Barros FC, Bhutta ZA (2013) The methodology of the INTERGROWTH-2 $1^{\text {st }}$ project. Int J Obstet Gynaecol 120(2):1-6
Passemard S, Kaindl AM, Verloes A (2013) Microcephaly. Pediatr Neurol Part I 129-141. https://doi.org/10.1016/b978-0-444-528919.00013-0

Pierson, TC and Diamond, MS (2018). The emergence of Zika virus and its new clinical syndromes. Nature 560:573-581. https://doi.org/10. 1038/s41586-018-0446-y

Pomar L, Vouga M, Lambert V, Pomar C, Hcini N, Jolivet A, Benoist G, Rousset D, Matheus S, Malinger G, Panchaud A, Carles G, Baud D (2018) Maternal-fetal transmission and adverse perinatal outcomes in pregnant women infected with Zika virus: prospective cohort study in French Guiana. BMJ 363:k4431. https://oi.org/10.1136/ bmj.k4431

Quicke KM, Bowen JR, Johnson EL, McDonald CE, Ma H, O'Neal JT, Rajakumar A, Wrammert J, Rimawi BH, Pulendran B, Schinazi RF, Chakraborty R, Suthar MS (2016) Zika virus infects human placental macrophages. Cell Host Microbe 20(1):83-90. https://doi.org/10. 1016/j.chom.2016.05.015

Russo FB, Jungmann P, Beltrão-Braga PCB (2017) Zika infection and the development of neurological defects. Cell Microbiol 19(6). https:// doi.org/10.1111/cmi.12744

Simmonds P, Becher P, Bukh J, Gould EA, Meyers G, Monath T, Muerhoff S, Pletnev A, Rico-Hesse R, Smith DB, Stapleton JT (2017) Ictv report consortium. ICTV virus taxonomy profile: flaviviridae. J Gen Virol 98(1):2-3. https://doi.org/10.1099/jgv.0. 000672

Simpson, DI (1964). Zika Virus Infection in Man. Trans R Soc Trop Med Hyg 58:335-338. https://doi.org/10.1016/0035-9203(64)90200-7

Walter LT, Higa GSV, Ikebara JM, Vedovello D, Salvador FS, Takada SH, Kinjo ER, Whalley BJ, Sperança MA, Kihara AH (2018) Evaluation of possible consequences of Zika virus infection in the developing nervous system. Mol Neurobiol 55(2):1620-1629. https://doi.org/ 10.1007/s12035-017-0442-5

Weaver SC, Reisen WK (2010) Present and future arboviral threats. Antivir Res 85(2):328-345. https://doi.org/10.1016/j.antiviral. 2009.10.008

Wheeler AC, Ventura CV, Ridenour T, Toth D, Nobrega LL, Silva de Souza Dantas LC, Rocha C, Bailey DB Jr, Ventura LO (2018) Skills attained by infants with congenital Zika syndrome: pilot data from Brazil. PLoS One 13(7):0201495. https://doi.org/10.1371/journal. pone. 0201495

World Heath Organization (WHO) (2016) Zika virus disease: Interim case definition. Available via http://www.who.int/iris/handle/ 10665/204381. Acessed 23 Jan 2019

Zanluca C, Melo VCA, Mosimann ALP, Santos GIV, Santos CND, Luz K (2015) First report of autochthonous transmission of Zika virus in Brazil. Mem Inst Oswaldo Cruz 110(4):569-572. https://doi.org/10. 1590/0074-02760150192

Zhang FC, Li XF, Deng YQ, Tong YG, Qin CF (2016) Excretion of infectious Zika virus in urine. Lancet Infect Dis 16(6):641-642. https://doi.org/10.1016/S1473-3099(16)30070-6

Publisher's note Springer Nature remains neutral with regard to jurisdictional claims in published maps and institutional affiliations. 